\title{
Abundance, density and habitat use of lowland paca (Cuniculus paca, Rodentia: Cuniculidae) in the Lacandon Rainforest, Chiapas, Mexico
}

\author{
Avril Figueroa-de-León ${ }^{1 *}$, Eduardo J. Naranjo', Hugo Perales ${ }^{1}$, Antonio Santos-Moreno² and Consuelo Lorenzo \\ ${ }^{1}$ El Colegio de la Frontera Sur. Carretera Panamericana y Periférico Sur s/n, , CP. 29290, San Cristóbal de Las Casas. Chiapas, \\ México. Email: mantabella@hotmail.com (AFL), enaranjo@ecosur.mx (EN), hperales@ecosur.mx (HP), clorenzo@ecosur.mx (CL). \\ ${ }^{2}$ Laboratorio de Ecología Animal, Centro Interdisciplinario de Investigación para el Desarrollo Integral Regional, Unidad Oaxaca, \\ Instituto Politécnico Nacional. Hornos No. 1003, Col. La Noche Buena, CP. 71230, Santa Cruz Xoxocotlán. Oaxaca, México. Email: \\ asantosm90@hotmail.com (ASM). \\ * Corresponding author
}

In this study, the effect of relevant variables (availability of food and cavities, competition, predation, and hunting pressure) on the relative abundance and population density of the spotted lowland paca (Cuniculus paca) was assessed. In addition, habitat use of this species at three sites with different land use regime (Montes Azules Biosphere Reserve, community reserves, and anthropic sites) in the Lacandon Rainforest, Chiapas, Mexico was analysed. From the perspective of the source-sink systems, it was predicted that pacas selectively would use the habitat with higher food and cavity availability (source habitats), where higher densities were expected. Twelve transects were located in three sites with different land use regimes, where food availability and potential cavities used by pacas were assessed. Along these transects, 4 camera-traps were deployed every 200 meters to estimate the relative abundance of pacas and their potential competitors and predators. Photo-captured individuals were identified to estimate population density and seasonal variation in habitat use. Generalized linear models (GLM) were constructed to analyse the effects of several variables on paca abundance and density. A relative abundance of 0.05 and 0.08 paca photographs/100 camera-days were recorded in the dry and the rainy season, respectively. A density of 54 pacas $/ \mathrm{km}^{2}$ was estimated in both seasons. The availability of cavities was the only variable that showed a significant effect on paca density $(P=0.04$ for the dry season, and $P=$ 0.006 for the rainy season). Community reserves were used in the dry season more than expected from their availability in the study area ( $x^{2}=$ $28.8 ; P=0.0001)$. In the rainy season, all three sites were used by paca in proportion to their availability. Our results suggest that the cavities used as refuges by pacas drive their population dynamics, and constitute a key habitat resource for them in the study area. We propose that the Ejidal Reserve and Montes Azules Biosphere Reserve may be source habitats supporting higher paca densities and greater availability of adequate cavities to protect adults and their offspring. On the other hand, areas transformed into croplands and grasslands for livestock production would represent sink habitats with lower paca densities, less availability of adequate cavities, and absence of offspring. The long-term conservation and habitat management of pacas in transformed landscapes will probably rely on the distribution and connectivity between and within the different habitat types available in the study area.

En este estudio, se evaluó el efecto de variables (disponibilidad de alimento y cavidades, competencia, depredación y presión de cacería) sobre la abundancia y densidad poblacional de Cuniculus paca. Se determinó el uso de hábitat de esta especie en tres sitios con distinto uso de suelo (Reserva de la Biosfera Montes Azules, reservas ejidales y sitios antrópicos) en la Selva Lacandona, Chiapas, México. Desde la perspectiva de los sistemas fuente-sumidero, se propuso que C. paca utilizaría selectivamente el hábitat con mayor disponibilidad de alimento y cavidades (hábitats fuente), donde presentaría mayor densidad poblacional. Se realizaron 12 transectos en tres sitios con diferente uso de suelo, donde se estimó la disponibilidad de alimento y cavidades potenciales para C. paca. A lo largo de éstos, se colocaron 4 trampas-cámara (cada 200 m) para determinar la abundancia relativa del tepezcuintle, sus competidores potenciales y depredadores. Por medio de la identificación de individuos a través de las foto capturas, se obtuvo la densidad, misma con la que se determinó el uso de hábitat por medio de pruebas de chi-cuadrada e intervalos de Bonferroni. Se construyeron modelos lineales generalizados para analizar el efecto de diversas variables sobre la abundancia y densidad de C. paca. En temporada seca se registraron 0.05 fotografías/100 días-cámara y en la de lluvias 0.08 fotografías/100 días-cámara, además de una densidad de 54 individuos $/ \mathrm{km}^{2}$ en ambas temporadas. La disponibilidad de cavidades fue la única variable que mostró efecto significativo sobre las densidades del tepezcuintle ( $P=0.04$ temporada seca, $P=0.006$ temporada de lluvias). Las reservas ejidales en temporada seca, se utilizaron más de lo esperado con base en su disponibilidad $\left(X^{2}=28.8 ; P=0.0001\right)$. En la temporada lluviosa, los tres hábitats fueron utilizados en proporción a su disponibilidad. Los resultados sugieren que las cavidades utilizadas como refugio estarían direccionando las dinámicas poblacionales del tepezcuintle y son un recurso clave dentro de los requerimientos de hábitat de esta especie en la zona de estudio. Se propone que la Reserva Ejidal y la Reserva de la Biósfera Montes Azules podrían considerarse hábitat fuente, ya que ambos contaron con mayor disponibilidad de cavidades adecuadas para la protección de los adultos y sus crías, mayores densidades, además de la presencia de crías tomada como indicador del éxito reproductivo. Por su parte, el hábitat antrópico sería sumidero, por tener menor disponibilidad de cavidades adecuadas, menor densidad poblacional y ausencia de crías. La conservación a largo plazo y manejo de hábitat del tepezcuintle en paisajes transformados, dependerán en gran parte de la distribución y conectividad entre y dentro de los diferentes tipos de hábitats.

Keywords: cavities; food; hunting pressure; rodent; source-sink.

๑ 2017 Asociación Mexicana de Mastozoología, www.mastozoologiamexicana.org 


\section{Introduction}

Natural and man-made disturbance often result in discontinuous landscapes and shifts in land cover (Cuarón 2000) representing habitat loss and habitat fragmentation for many wildlife species. These are among the primary drivers of population declines and species extinctions (Caughley et al. 1996). Once a habitat gets fragmented, its resource availability shifts, producing variations in animal population densities and distributions (Pulliam and Danielson 1991). This situation may be analyzed using the source-sink system approach, where source fragments provide most of the essential resources for the survival and reproductive success of wildlife species. Therefore, natality rates usually are higher than mortality rates in source habitat, which may get to the point of reaching carrying capacity in such fragments. Surplus individuals may migrate into lower quality (sink) fragments, where mortality overcomes natality. Consequently, local populations in sink habitats rarely persist in the long term without immigration from source fragments (Pulliam and Danielson 1991; Hanski and Simberloff 1997).

A population may be distributed across source and sink fragments, giving place to subpopulations with different growth, natality, and mortality rates depending on available resources (e.g. food and shelter; Pulliam and Danielson 1991). When the resources within a habitat are used with higher frequency in relation to their availability, selectivity is inferred (Johnson 1980). The use of resources and their importance for a particular species vary as function of a series of factors that should be recognized to better evaluate the habitat requirements of animal species (Chalfoun and Martin 2007), especially those affected by habitat loss and unregulated hunting, as it happens to the spotted lowland paca Cuniculus paca (Cuarón 2000; Urquiza-Haas et al. 2009). The paca is a solitary and nocturnal Neotropical rodent. Pacas rest during the day inside underground cavities where their newborns are raised and kept apart from both predators and adverse weather conditions. This mammal occurs in a wide array of ecosystems such as different kinds of tropical forests, montane forests, mangroves, and riverine vegetation (Pérez 1992). Pacas feed mainly on fruit, contributing to seed dispersal and seed predation of many tropical tree species (Pérez 1992; Dubost and Henry 2006). Pacas are also important food items for predators such as jaguars (Panthera onca), pumas (Puma concolor), and ocelots (Leopardus pardalis; Pérez 1992; Eisenberg and Redford 2000). Besides, the paca has always been a primary prey for Neotropical subsistence hunters, who regard this species as very relevant in cultural and nutritional terms (Weitlaner 1997; Corona and Enríquez 2011). Currently, this mammal is heavily pursued by hunters in every place it can be found, particularly in southern Mexico, where it is often the most hunted and consumed wild mammal due to the relative easiness of its capture and the excellent taste of its meat (Naranjo et al. 2004; Centeno and Arriaga 2010).

The paca is relatively tolerant to habitat fragmentation and land use change in the tropical forests of Mexico (Cuarón 2000; Gallina et al. 2012). During the second half of the twen- tieth century, over $50 \%$ of the original cover of the Lacandon Rainforest, Chiapas, Mexico has been lost (Vásquez-Sánchez and Ramos 1992). Habitat loss and fragmentation coupled to heavy hunting pressure in southern Mexico (Naranjo et al. 2004), may be primary drivers to paca population declines and even local extinctions (Estrada et al. 1994). Thus, it is of utmost importance to improve our knowledge on paca populations and their habitat requirements in the wild as well as in transformed landscapes. This information will support sound management plans and actions for sustainable use and conservation of paca populations.

In this study, we evaluated the effect of different variables (availability of food and cavities, interspecific competition, predation, and hunting pressure) on abundance and density of C. paca. In addition, we analyzed habitat use by pacas from a source-sink systems perspective in sites with three different land uses: Montes Azules Biosphere Reserve, community reserves, and agricultural landscapes of the Lacandon Rainforest. We expected that paca abundance and density would be positively associated to the availability of food and cavities, and negatively correlated to interspecific competition, predation, and hunting pressure. We predicted that pacas would prefer habitats with more food available, and cavities resistant to predation and hunting, which would favor their survival and reproductive success. Preferred (source) habitat types would show higher paca densities than the others.

\section{Materials and Methods}

Study area The study area included a southeastern portion of Montes Azules Biosphere Reserve (MABR) and territories of two neighboring communities (ejidos): Playón de la Gloria (pop = 209), and Reforma Agraria ( $p o p=145$ ) in the Lacandon Rainforest of Chiapas, Mexico. Both communities are located on the east side of the Lacantun River (INE 2000; INEGI 2010). Three habitat types were considered in this study: 1) Transformed landscapes, including secondary vegetation along rivers and within agricultural and grazing areas, and human settlements. Human presence in this habitat type was continuous; 2) Community reserves, established by local residents for conservation in Reforma Agraria (14.6 km²) and Playon de la Gloria $\left(2.5 \mathrm{~km}^{2}\right)$. Both reserves are primarily covered by secondary forest, abandoned plantations, and rainforest fragments. Tourism and research are present in these reserves for relatively short periods (a month or less); 3) Montes Azules Reserve, where undisturbed mature rainforest is predominant. Human activity is negligible in this site, where only a few researches and visitors are allowed (Figure 1).

Fieldwork. Monthly samplings were carried out in the study sites from September 2013 through August 2014. Four line transects were walked in each habitat type for each season ( $d r y=$ December-May, wet = June-November). Each transect was $1 \mathrm{~km}$ long and $50 \mathrm{~m}$ wide (Figure 1). A minimum distance of $175 \mathrm{~m}$ between transects was set for sampling independence based on the average home range of the paca (1.74 ha; Beck-King et al. 1999). Our cri- 


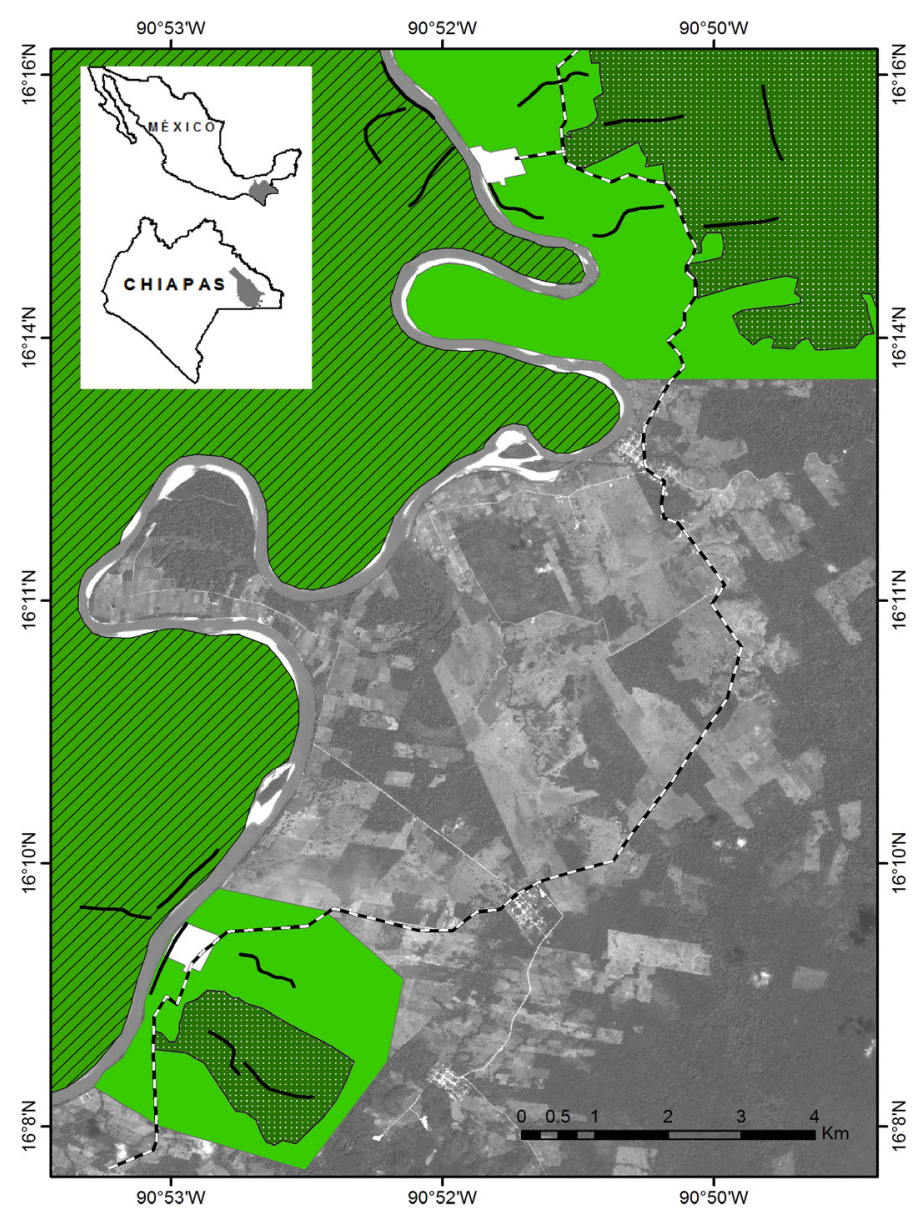

Figure 1. Location of the study site in the Lacandon Rainforest, Chiapas, Mexico. Transects (black lines) and habitat types are shown: Transformed landscape (light plain green), Community reserve (dark dotted green), and Montes Azules Biosphere Reserve (MABR; green with diagonal lines). Human settlements are represented with a white square: Reforma Agraria in the upper part, and Playon de la Gloria in the lower part.

terion to select transect locations was the presence of paca signs (footprints, feeding sites, active burrows, and sights by residents). Four camera-traps were deployed every 200 meters along each transect in order to estimate the relative abundance of pacas and their potential competitors and predators. That distance was considered appropriate for independence of paca records (Karanth and Nichols 1998 ) and for its competitors of similar or smaller size. For larger competitors and predators such as the white-tailed deer (Odocoileus virginianus), red brocket deer (Mazama temama), Baird's tapir (Tapirus bairdii), collared peccary (Pecari tajacu), white-lipped peccary (Tayassu pecari), jaguar (Panthera onca), puma (Puma concolor), ocelot (Leopardus pardalis), tayra (Eira barbara), and dogs (Canis lupus familiaris), the minimum distance for independent records was $1 \mathrm{~km}$ (Maffei and Noss 2008; Naranjo et al. 2015). Cameratraps (models Moultrie D55, Stealth-Cam Q8X, and Bushnell Trophy XLT) were programmed to be active 24 hours for 30 consecutive days each season, taking 3 still pictures and a short video (10 to $20 \mathrm{sec}$ ) per event. Records were considered independent if taken in different transects and days, unless individual identification was possible (MonroyVilchis et al. 2011; Jax et al. 2015). Capture rates were estimated by calculating the number of independent records (pictures) of pacas in relation to the total number of effective records of all species per season and habitat type. Effective pictures were those where pacas or their potential competitors and predators appeared (Pérez 1992; Dubost and Henry 2006; Figueroa-de-León et al. 2016a).

Relative abundance indices of pacas and other mammals (Appendix 1) were estimated using photo-trapping data $\left(\mathrm{RAI}_{\mathrm{ft}}\right)$. These indices were calculated as follows: $\mathrm{RAI}_{\mathrm{ft}}$ $=$ number of independent records (pictures or videos) of C. paca / total effective pictures / sampling effort per 100 camera-days (Carbone et al. 2001). The density of pacas was assessed by counting the individuals photo-captured along each transect. Individuals recorded during abundance monitoring and photographic records previously obtained in cavities occupied by pacas (Figueroa-de-León et al. 2016a) were taken into account for density estimations. Individual identification was based on descriptions of pacas made by Figueroa-de-León et al. (2016a). Diffuse pictures were excluded from this analysis.

Food availability for pacas was evaluated by establishing five $1,000 \mathrm{~m}^{2}$ circular plots along each transect. The distance between centers of two contiguous plots was 200 $\mathrm{m}$ (Elzinga et al. 2001). All trees and palms within plots producing fruits potentially consumed by pacas (Beck-King et al. 1999; Muñoz et al. 2002; Zucaratto et al. 2010) were counted and marked. Field observations of fruits bitten by pacas and references by local hunters were also helpful for selecting the tree species considered in this analysis. Samples of leaves, flowers and fruits of each tree species were collected for taxonomic determination in the Herbarium at El Colegio de la Frontera Sur, San Cristóbal de Las Casas, Chiapas. Fruit production in each habitat type was monitored monthly between September 2013 and August 2014. Mean area under the tree crown and the average number of fallen fruits per tree were counted for each of the 30 tree species recorded. Fallen fruit counts were done monthly in 5-10 circular plots with a radius of $0.5 \mathrm{~m}$ (fruits up to $3 \mathrm{~cm}$ diameter) and $1 \mathrm{~m}$ (fruits over $3 \mathrm{~cm}$ diameter). All counted fruits were removed from the plots to avoid double counts in subsequent samplings. Collected fruits were taken to the bromatology lab at El Colegio de la Frontera Sur, where fruit parts were separated to estimate the biomass available as paca food (Beck-King et al. 1999; Muñoz et al. 2002; Zucaratto et al. 2010; Appendix 2). Fruit parts were dehydrated at $60^{\circ} \mathrm{C}$ until constant weight (adapted from Wallace and Painter 2003). The numbers of fallen fruits per tree species were multiplied by the average dry weight of all parts consumed by pacas (Ganesh and Davidar 1999). Available food estimates from all tree species were pooled to obtain food availability indices by habitat type and season.

In April (dry season) and September (wet season) 2013 we intensively searched for cavities used as refuges by pacas. This search was done along each transect $(1,000$ x $50 \mathrm{~m}$ ) from 7:00 through 16:00. All cavities found were examined, including those under the forest floor, within tree roots or fallen logs. Cavities were considered avail- 
able for pacas if they were at least $15 \mathrm{~cm}$ in diameter, $60 \mathrm{~cm}$ deep (Aquino et al. 2012), and located at $100 \mathrm{~m}$ or less from the nearest water source (Figueroa-de-León et al. 2016a,b). Only cavities with indicators of recent activity (fresh tracks, fresh litter around, and clean entrance were considered. A minimum distance of $100 \mathrm{~m}$ between cavities was taken as a criterion for spatial independence (Beck-King et al. 1999). An index of cavity availability was estimated by dividing the number of available cavities by the total area sampled in each habitat type and season.

Hunting pressure on pacas was estimated by gathering information consisting of hunted paca carcasses found during fieldwork, paca cavities destroyed by hunters, pictures and videos of hunters and their dogs nearby cavities, platforms for hunting built on trees, personal observations of hunting by the authors, and comments by residents about the presence of paca hunters in their communities. A persistently hunted transect was that in which a hunting evidence was detected at least once a month, or when there were 2 to 3 weekly references about paca hunters present. A slightly hunted transect showed no frequent hunting evidence or weekly references. In addition, a hunting pressure index was built by dividing the number of persistently hunted transects by the number of slightly hunted transects in each habitat type and season. Habitat use by pacas was assessed by estimating their densities in the three habitat types and both seasons. The total available habitat was the sum of sampled areas in each transect, habitat type, and season (Morrison et al. 2006).

Data analyses. Paca abundance, density, food and cavity availability, and hunting pressure were compared among habitat types and between seasons using Wilcoxon's signed-rank tests, Kruskal-Wallis's analysis of variance on ranks tests, and Pearson's Chi-squared tests of independence with Yates's correction of continuity (Crawley 2005). Durbin and Watson's tests were used to verify independence in our abundance and density data (Crawley 2005). Generalized Linear Models (GLM; McCullagh and Nelder 1989 ) were built to determine the effect of explaining variables (food and cavity availability, hunting pressure, competition, and predation) on paca density and abundance indices. Because of our limited sample size (13 and 12 transects in dry and wet season, respectively), each model was built with a single explaining variable at a time. A Poisson distribution was assumed in the GLM unless an over-dispersion due to zero predominance in data was present. In such cases, a negative binomial distribution was assumed (Crawley 2005). All statistical procedures were applied using packages MASS (Venables and Ripley 2002), and Imtest (Zeileis and Hothorn 2002) in R platform version 3.3-1 (R Core Team 2016). HABUSE program (Neu et al. 1974; Byers et al. 1984) was used to assess habitat use based on paca abundance and its habitat availability. By running Chi-squared tests and Bonferroni's confidence intervals in this program, we detected preference or avoidance of each habitat type by pacas in the study area (Neu et al. 1974; Byers et al. 1984).

\section{Results}

A total of $125.3 \mathrm{~km}$ were walked and an area of 125 hectares was sampled in the study area. A sampling effort of 2,226 camera-days resulted in 5,745 photographic records of 23 mammal species. Of these records, 1,026 were considered effective photographs and 191 of them corresponded to C. paca. Paca relative abundance was slightly lower in the dry season than in the wet season $(0.01$ versus 0.02 photographs/100 camera-days, respectively). However, no significant differences were found between seasons $(W=77.5$, $P=1)$ and among habitat types in dry $\left(X^{2}=0.2, P=0.9\right)$ and wet $\left(X^{2}=2.8, P=0.2\right)$ seasons. Paca densities were similar between seasons ( $d r y=0.56$ pacas $/$ ha, wet $=0.54$ pacas $/$ ha; $\mathrm{W}=77.5, P=0.99)$ and among habitat types $(P>0.05)$.

Food availability for pacas was estimated under the crown of 297 trees of 30 species, of which 5 species produced fruit in the dry season, 16 in the wet season, and 8 in both seasons. A lower food availability was found in the dry season compared to the wet season ( $\mathrm{W}=125, P=$ 0.009). Nonetheless, there were no differences among habitat types $(P>0.05$; Table 1$)$. Cavity availability was similar between seasons ( $\mathrm{W}=61.5, P=0.4$ ), and among habitat types $(P>0.05 ;$ Table 1$)$. Similarly, we detected no seasonal $\left(X^{2}=0.04, P=0.8\right)$ or habitat-based $(P>0.05$; Table 1$)$ differences in the numbers of persistently hunted versus slightly hunted transects in the study area.

Potential paca competitors recorded by photo-trapping in MABR were: Red brocket deer, Baird's tapir, collared peccary, nine-banded armadillo (Dasypus novemcinctus), agouti (Dasyprocta punctata), opossums (Didelphis spp., Philander opossum, and Metachirus nudicaudatus), and great curassow (Crax rubra). In the community reserve we detected the white-tailed deer, red brocket deer, Baird's tapir, raccoon (Procyon lotor), coati (Nasua narica), ninebanded armadillo, opossums, great curassow, and green iguana (Iguana iguana). In the transformed landscapes, the red brocket deer, Baird's tapir, collared peccary, and great curassow were registered. Potential predators detected through photo-trapping in MABR were the ocelot and tayra; the jaguar, puma, and dogs were recorded in the

Table 1. Relative abundance indices, densities, food and cavity availability indices, and hunting pressure on Cuniculus paca in three habitat types of the Lacandon Rainforest Chiapas, Mexico (2013-2014). The following units were used: Relative abundance index (RAI): photographs/100 camera-days; density: pacas/ha; food availability index (FAl): kg/ ha; cavity availability index (CAl): number of cavities/ ha; hunting pressure index (HPI): number of persistently hunted transects/ number of slightly hunted transects.

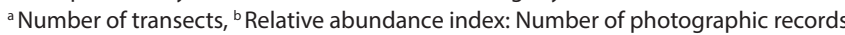
of pacas / total effective photographs / days * 100. 'Biomass (dry weight of edible parts of fallen fruits, kg) / ha of each habitat type. ${ }^{d}$ Total cavities available / ha sampled in each habitat type. ${ }^{e}$ Persistently hunted transects / slightly hunted transects. ${ }^{\mathrm{f}}$ MABR: Montes Azules Biosphere Reserve.

\begin{tabular}{|c|c|c|c|c|c|c|c|}
\hline Season & Habitat type & $\begin{array}{l}\text { n } \\
\mathbf{a}\end{array}$ & RAI $^{\mathbf{b}}$ & Density & FAl' & $C A I^{d}$ & $\mathrm{HPI}^{\mathrm{e}}$ \\
\hline \multirow{3}{*}{ Dry } & Transformed & 4 & 0.04 & 0.41 & 12505 & 0.40 & 1 \\
\hline & Comm. Reserve & 4 & 0.08 & 0.82 & 5088 & 0.65 & 1 \\
\hline & $\mathrm{MABR}^{f}$ & 5 & 0.02 & 0.44 & 9561 & 0.52 & 0.6 \\
\hline \multirow{3}{*}{ Wet } & Transformed & 4 & 0.08 & 0.41 & 20945 & 0.25 & 0.3 \\
\hline & Comm. Reserve & 4 & 0.13 & 0.56 & 11919 & 0.45 & 1 \\
\hline & MABR $^{f}$ & 4 & 0.04 & 0.65 & 48226 & 0.50 & 0.3 \\
\hline
\end{tabular}


community reserve, and no predators were recorded in the transformed landscape.

Paca relative abundance was no significantly affected by food and cavity availability, hunting pressure or abundance of competitors and predators (Appendices 3 and 4). Contrastingly paca density was positively correlated with cavity availability (dry season: $r=0.15, P=0.04$; wet season: $r=$ $0.22, P=0.006)$. In the dry season, pacas used the transformed landscape in proportion to its availability, the community reserve more than expected, and MABR less than expected. However, during the wet season the three habitat types were used by pacas in proportion to their availability (Table 2).

Table 2. Habitat use and availability of Cuniculus paca in the Lacandon Rainforest, Chiapas, Mexico (2013-2014). HAB=Habitat type. Available habitat in the transformed landscape and the community reserve: 20 ha (dry and wet seasons). Available habitat in Montes Azules Biosphere Reserve (MABR): 25 ha (dry season), 20 ha (wet season). ${ }^{a}$ OBS: observed proportion of use. 'EXP: expected proportion of use. INTERVAL: Bonferroni's confidence intervals. "HU: habitat use by paca, where "=": used in proportion to availability; "+": used greater than expected (selected habitat); "-": used lower than expected $(P=0.05)$.

\begin{tabular}{|c|c|c|c|c|c|c|c|c|}
\hline \multirow[t]{2}{*}{ HAB } & \multicolumn{4}{|c|}{$\begin{array}{c}\text { Dry season } \\
\mathrm{X}^{2}=28.8 ; \mathrm{P}=0.0001\end{array}$} & \multicolumn{4}{|c|}{$\begin{array}{c}\text { Wet season } \\
X^{2}=4.8 ; P=0.08\end{array}$} \\
\hline & $\mathrm{OBS}^{\mathrm{a}}$ & INTERVAL ${ }^{b}$ & EXPc & $H U^{d}$ & OBS $^{a}$ & INTERVAL & EXPc & $H U^{d}$ \\
\hline Transformed & 0.246 & $0.166-0.325$ & 0.30 & $=$ & 0.253 & $0.171-0.335$ & 0.33 & $=$ \\
\hline $\begin{array}{l}\text { Comm. } \\
\text { Reserve }\end{array}$ & 0.491 & $0.398-0.584$ & 0.30 & + & 0.346 & $0.256-0.435$ & 0.33 & $=$ \\
\hline MABR & 0.263 & $0.182-0.345$ & 0.39 & - & 0.401 & $0.309-0.493$ & 0.34 & $=$ \\
\hline
\end{tabular}

\section{Discussion}

Similarities in paca abundances and densities between seasons and among habitat types may have been due to our limited sample sizes (13 and 12 transects in dry and wet seasons, respectively), which make difficult to detect potential differences. In addition, paca abundance indices may be skewed because differences in capture probabilities across seasons and habitat types were not considered. Capture probabilities are conditioned by factors such as individual behavior and physical condition, cover type around camera-traps, and weather, among others ( $\mathrm{O}^{\prime}$ Connell et al. 2010). These factors may be confounding potential effects of variables explaining paca abundance. Similarly, density estimates could have been subject to problems in distinguishing paca individuals because of low resolution of night pictures, and distance impairing the observation of the spot pattern of some pacas (Figueroa-de-León et al. 2016a). In spite of this, cavity availability was the only variable with a significant link with paca densities, which suggests that cavities constitute a key resource driving paca population dynamics in the study area.

Food availability did not show a significant effect on paca density and abundance. This can be partially explained by the methodological limitations mentioned above, or by the opportunistic behavior of pacas (Laska et al. 2003), which may adjust their diet following seasonal and spatial variations in fruit availability (Dubost and Henry 2006). Hunting pressure had no effect on paca density and abundance, which may be due to the relatively low frequency of hunting practices in the communities visited in this study. Yet, it is important to encourage multiannual surveys for better understanding the impact of hunting on paca population dynamics and its persistence in transformed landscapes.

The abundance of competitors did not have an effect on paca populations, probably because the ecological and behavioral traits of pacas (nocturnal activity, opportunist diet, and cavity use for avoiding predation; Aquino et al. 2009), allow them to reduce the encounter probability with other species. On the other side, the abundance of potential predators was unrelated to paca abundance. A likely explanation to this result is the fact that pacas reduce their predation risk by taking cover inside safe cavities such as those under tree roots or in fallen logs (Figueroa-de-León et al. 2016a, b), which are frequently located at strategic sites (i. e., near water courses that can be used as routes for escaping from predators; Aquino et al. 2009).

Pacas selectively used the community reserve of Playon de la Gloria during the dry season, probably due to the existence of a rocky area with multiple cavities of the appropriate size to avoid predation and hunting. In contrast, the three habitat types considered in this study were used in proportion to their availability during the wet season. This may be explained by: 1) An increase in paca movements favored by a shortage of cavities produced by seasonal floods or collapse of burrows; 2) food and water abundance. Proximity to permanent water sources has been documented as a key variable for selective use of cavities by pacas (Figueroa-de-León et al. 2016a). Similarly, water bodies have proven key habitat elements related to paca defecation (Figueroa-de León et al. 2016b) and reproduction (Epigmenio Cruz Aldán, Tuxtla Gutierrez Zoo, Chiapas, Mexico 2016 comm. pers.). Therefore, food and water abundance during the wet season reflects in lack of habitat selectivity by pacas in the study area.

In summary, we found that cavity availability had an effect on paca densities, which highlights the relevance of those habitat components on the population dynamics of this rodent in our study area. Besides, cavities used by pacas as shelters to avoid predation and adverse weather constitute habitat resources of utmost importance for pacas in the Lacandon Rainforest (Figueroa-de-León et al. 2016a). Thus, source habitats for pacas such as MABR and the community reserve of Playon de la Gloria have high availability of cavities favoring higher paca densities and reproductive rates inferred from higher frequencies of newborns (Figueroa-de-León et al. 2016a). On the contrary, sink habitats for pacas such as the transformed landscape included in this study have lower availability of appropriate cavities, lower densities and absence of newborns (Figueroa-deLeón et al. 2016a).

Conserving wildlife species tolerant to land use change (i. e., the paca) in transformed landscapes will depend on their habitat requirements as well as the distribution and 
connectivity of habitat fragments available (Ye et al. 2013). Hence, habitat types with continuous, mature cover are as important for paca conservation and management as secondary forest fragments interconnected to the first (Jax et al. 2015). Habitat connectivity is fundamental for paca mobility and dispersal, improving the viability of its populations in the long term (Ahumada et al. 2003; Gallina et al. 2012).

\section{Acknowledgments}

We thank the National Council for Science and Technology of Mexico (CONACYT) for the grant given to the first author for doctoral studies. Idea Wild and El Colegio de la Frontera Sur (ECOSUR) provided partial funding for this project. ECOSUR's Geographic Analysis Lab, Bromatology Lab, and Herbarium facilitated equipment and infrastructure for the study. The Instituto Politécnico Nacional (IPN) provided part of the field equipment. We are very grateful with the residents and guides of ejidos Playon de la Gloria and Reforma Agraria for their help and hospitality during the fieldwork: R. Jiménez, A. Rodríguez, B. Hernández, C. Chan, C. Hernández, and Y. de la Rosa. Thanks to our colleagues who helped to improve this manuscript in different ways: M. González, M. Martínez Ico, M. Ishiki, G. Pérez Escobar, J. R. Vásquez, Y. Martínez, G. Martínez, and R. Velázquez.

\section{Literature Cited}

Ahumada, J. A., J. Hurtado, and D. Lizcano. 2013. Monitoring the status and trends of tropical forest terrestrial vertebrate communities from camera trap data: A tool for conservation. PLoS ONE 8:e73707.

Aquino, R., D. Gil, and E. Pezo. 2009. Aspectos ecológicos y sostenibilidad de la caza del majá (Cuniculus paca) en la cuenca del río Itaya, Amazonía peruana. Revista Peruana de Biología 16:67-72.

Aquino, R., G. Meléndez, E. Pezo, And D. Gil. 2012. Tipos y formas de ambientes de dormir de majás (Cuniculus paca) en la cuenca alta del río Itaya. Revista Peruana de Biología 19:27-34.

Aranda-SÁnchez, J. M. 2012. Manual para el rastreo de mamíferos silvestres de México. Comisión Nacional para el Conocimiento y Uso de la Biodiversidad (CONABIO). Ciudad de México, México.

Beck-King, H., O. Helversen, And R. Beck-King. 1999. Home Range, Population Density, and Food Resources of Agouti paca (Rodentia: Agoutidae) in Costa Rica: A Study Using Alternative Methods. Biotropica 31:675-685.

Byers, C. R., R. K. Steinhorst, And P. R. Krausman. 1984. Clarification of a technique for analysis of utilization-availability data. The Journal of Wildlife Management 48:1050-1053.

Carbone, C., S. Christie, K. Conforti, T. Coulson, N. Franklin, J. R. Ginsberg, And W. N. Shahruddin. 2001. The use of photographic rates to estimate densities of tigers and other cryptic mammals. Animal Conservation 4:75-79.

Caughley, G., A. Gunn, and K. Ralls. 1996. Conservation biology in theory and practice. Blackwell Science. Cambridge, Massachusetts.

Centeno, P., and S. Arriaga. 2010. Uso y aprovechamiento de fauna silvestre en comunidades del Parque Estatal de La Sierra, Tabasco, México. Pp. 53-77 in Uso y manejo de fauna silvestre en el norte de Mesoamérica (Guerra, M. M., S. Calmé, S. Gallina, and E. Naranjo, eds.). Secretaría de Educación del Gobierno del Estado de Veracruz. Veracruz, México.

Chalfoun, A. D., and T. E. Martin. 2007. Assessments of habitat preferences and quality depend on spatial scale and metrics of fitness. Journal of Applied Ecology 44:983-992.

Corona, M. E., AND P. EnríQuez. 2011. The historical use of terrestrial vertebrates in the Selva Region (Chiapas, México). Pp. 41-48 in Ethnozooarchaeology: The Present and Past of Humananimal Relationships (Albarella, U., and A. Trentacoste, eds.). Oxbow Books. Oxford, UK.

Crawley, M. J. 2005. Statistics: an introduction using R. John Wiley and Sons Ltd. New Jersey.

CUARÓN, A. D. 2000. Effects of land-cover changes on mammals in a neotropical region: a modelling approach. Conservation Biology 14:1676-1692.

Díaz-Pulido, A., and E. Payán. 2012. Manual de Fototrampeo: Una herramienta de investigación para la conservación de la biodiversidad en Colombia. Instituto de Investigaciones de Recursos Biológicos Alexander von Humboldt y Panthera Colombia. Bogotá, Colombia.

Dubost, G., and O. Henry. 2006. Comparison of diets of the acouchy, agouti and paca, the three largest terrestrial rodents of French Guianan forests. Journal of Tropical Ecology 22:641. EisenberG, J. F., AND K. H. Redford. 2000. Mammals of the Neotropics: Ecuador, Bolivia, Brazil. University of Chicago Press. Chicago.

Elzinga, C. L., D. W. Salzer, J. W. Willoughby, and J. P. GibBs. 2001. Monitoring plant and animal populations. Blackwell Malden. Cambridge, Massachusetts.

Estrada, A., R. Coates-Estrada, and D. Meritt, JR. 1994. Non flying mammals and landscape changes in the tropical rain forest region of Los Tuxtlas, Mexico. Ecography 17:229-241.

Figueroa-de-León, A., E. J. Naranjo, H. Perales, A. Santos-Moreno, AND C. LoREnzo. 2016a. Cavity occupancy by lowland paca (Cuniculus paca) in the Lacandon Rainforest, Chiapas, Mexico. Tropical Conservation Science 9:246-263.

Figueroa-de León, A., E. J. Naranjo, H. Perales, A. Santos-Moreno, and C. LoRENZO. 2016b. Availability and characterization of cavities used by pacas (Cuniculus paca) in the Lacandon Rainforest, Chiapas, Mexico. Revista Mexicana de Biodiversidad 87:10621068.

Gallina, S., J. Pérez-Torres, and C. C. Guzmán-Aguirre. 2012. Use of the paca, Cuniculus paca (Rodentia: Agoutidae) in the Sierra de Tabasco State Park, Mexico. Revista de Biología Tropical 60:1345-1355.

Ganesh, T., AND P. Davidar. 1999. Fruit biomass and relative abundance of frugivores in a rain forest of southern Western Ghats, India. Journal of Tropical Ecology 15:399-413.

HANSKI, I., AND D. SimberlofF. 1997. The metapopulation approach, its history, conceptual domain, and application to conservation. Pp. 5-26 in Metapopulation Biology (Hanski, I., and M. E. Gilpin, eds.). Academic Press. San Diego, U. S. A. Instituto Nacional de Ecología - Ine. 2000. Programa de Manejo Reserva de la Biosfera Montes Azules. INE. Ciudad de México, México.

Instituto naCional de Estadística y Geografía - INEGI. 2010. Consulta de Localidades ITER 2010. www.inegi.org.mx/sistemas/ consulta_resultados/iter2010.aspx 
Jax, E., S. Marín, A. Rodríguez-Ferraro, and E. Isasi-Catalá. 2015. Habitat use and relative abundance of the Spotted Paca Cuniculus paca (Linnaeus, 1766) (Rodentia: Cuniculidae) and the Red-rumped Agouti Dasyprocta leporina (Linnaeus, 1758) (Rodentia: Dasyproctidae) in Guatopo National Park, Venezuela. Journal of Threatened Taxa 7:6739-6749.

JoHnson, D. H. 1980. The comparison of usage and availability measurements for evaluating resource preference. Ecology 61:65-71.

Karanth, K. U., and J. D. Nichols. 1998. Estimation of tiger densities in India using photographic captures and recaptures. Ecology 79:2852-2853.

Laska, M., J. M. Luna Baltazar, and E. Rodriguez Luna. 2003. Food preferences and nutrient composition in captive pacas, Agouti paca (Rodentia, Dasyproctidae). Mammalian Biology 68:31-41.

Maffel, L., AND A. J. Noss. 2008. How Small is too small? Camera Trap survey areas and density estimates for ocelots in the Bolivian Chaco. Biotropica 40:71-75.

McCullagh, P., and J. A. Nelder. 1989. Generalized linear models. CRC Monographs on Statistics and Applied Probability. Springer Verlag. New York, U. S. A.

Monroy-Vilchis, O., M. M. Zarco-GonzÁlez, C. Rodríguez-Soto, L. SORIA-DíAZ, AND V. URIOS. 2011. Fototrampeo de mamíferos en la Sierra Nanchititla, México: abundancia relativa y patrón de actividad. Revista de Biología Tropical 59:373-383.

Morrison, M. L., B. MarCot, And W. Mannan. 2006. Wildlife-Habitat Relationships: Concepts and Applications. Island Press. Washington, U.S. A.

Muñoz, J., O. Betancur, And M. Duque. 2002. Patrones de hábitat y de actividad nocturna de Agouti paca en el Parque Nacional Utría (Chocó, Colombia). Actualidades Biológicas 24:75-85.

Naranjo, E. J., M. M. Guerra, R. E. Bodmer, and J. Bolanos. 2004. Subsistence hunting by three ethnic groups of the Lacandon forest, Mexico. Journal of Ethnobiology 24:233-253.

Naranjo, E. J., S. A. Amador-Alcala, F. A. Falconi-Briones, and R. A. ReYnA-HuRTAdo. 2015. Distribución, abundancia y amenazas a las poblaciones de tapir centroamericano (Tapirus bairdii) y pecarí de labios blancos (Tayassu pecari) en México. Therya 6: 227-249.

Neu, C. W., C. R. Byers, And J. M. Peek. 1974. A technique for analysis of utilization-availability data. Journal of Wildlife Management 38:541-545.

O'Connell, A. F., J. D. Nichols, and K. U. Karanth (eds.). 2010. Camera traps in animal ecology: methods and analyses. Springer Science and Business Media. New York.

Pérez, E. M. 1992. Agouti paca. Mammalian Species 404:1-7.

Potts, G., J. Coulson, and I. Deans. 1980. Population dynamics and breeding success of the shag, Phalacrocorax aristotelis, on the Farne Islands, Northumberland. The Journal of Animal Ecology 49:465-484.

Pulliam, H., and B. Danielson. 1991. Sources, sinks, and habitat selection: a landscape perspective on population dynamics. American Naturalist 137:S50-S66.

R CoRE TEAM. 2016. R: A language and environment for statistical computing. v3.3-1. R Foundation for Statistical Computing. Vienna, Austria. URL https://www.R-project.org/.

Sherry, T., And R. Holmes. 1988. Habitat selection by breeding American Redstarts in response to a dominant competitor, the Least Flycatcher. The Auk 105:350-364.

Sherry, T., AND R. Holmes. 1989. Age-specific social dominance affects habitat use by breeding American redstarts (Setophaga ruticilla): a removal experiment. Behavioral Ecology and Sociobiology 25:327-333.

Urquiza-HaAs, T., C. A. Peres, and P. M. Dolman. 2009. Regional scale effects of human density and forest disturbance on large-bodied vertebrates throughout the Yucatán Peninsula, Mexico. Biological Conservation 142:134-148.

VÁsquez-SÁnchez, M., And M. Ramos. 1992. Reserva de la Biosfera Montes Azules; Selva Lacandona: Investigación para su conservación. Centro de Estudios para la Conservación de los Recursos. Ecosfera. Available at: https://scholar.google.com. $\mathrm{mx} / \mathrm{scholar}$ hhl=es\&q=Vasquez+y+Ramos+1992\&btnG=\&lr=

Venables, W. N., AND B. D. Ripley. 2002. Modern applied statistics with S (Fourth). Springer. New York, U. S. A.

Wallace, R. B., And L. E. Painter. 2003. Metodologías para medir la fenología de fructificación y su análisis con relación a los animales frugívoros. Instituto de Ecología, Universidad Mayor de San Andrés. La Paz, Bolivia.

Weitlaner, R. J. 1997. Relatos, mitos y leyendas de la Chinantla. Instituto Nacional Indigenista. Colección INI 58. Ciudad de México, México.

Ye, X., A. K. SkIDmore, ANd T. Wang. 2013. Within-patch habitat quality determines the resilience of specialist species in fragmented landscapes. Landscape Ecology 28:135-147.

ZeILEIS, A., AND T. HOTHORN. 2002. Diagnostic checking in regression relationships. $\mathrm{R}$ News 2:7-10.

Zucaratto, R., R. Carrara, and B. K. Siqueira. 2010. Dieta da paca (Cuniculus paca) usando métodos indiretos numa área de cultura agrícola na Floresta Atlântica brasileira. Biotemas 23:235-239.

\section{Associated editor: Robert Owen}

Submitted: November 15, 2016; Reviewed: February 13, 2017;

Accepted:May 13, 2017; Published on line: September 1, 2017. 
Appendix 1. Relative abundance indices (RAI) of Cuniculus paca, its potential competitors and predators in three habitat types of the Lacandon Rainforest, Chiapas, Mexico (20132014). RAl: photographs/100 camera-days.

\begin{tabular}{|c|c|c|c|c|c|c|}
\hline & \multicolumn{3}{|c|}{ Dry season } & \multicolumn{3}{|c|}{ Wet season } \\
\hline & Transformed landscape & Community reserve & MABR $^{\mathbf{a}}$ & Transformed landscape & Community reserve & MABR $^{\mathbf{a}}$ \\
\hline Camera-days & 375 & 342 & 409 & 402 & 294 & 404 \\
\hline Photographs analyzed & 345 & 88 & 244 & 142 & 74 & 133 \\
\hline IAR Cuniculus paca & 0.04 & 0.08 & 0.02 & 0.08 & 0.13 & 0.04 \\
\hline \multicolumn{7}{|l|}{ Predators } \\
\hline IAR Leopardus pardalis & 0 & 0 & 0.01 & 0 & 0 & 0 \\
\hline IAR Panthera onca & 0 & 0 & 0 & 0 & 0.01 & 0 \\
\hline IAR Puma concolor & 0 & 0 & 0 & 0 & 0.01 & 0 \\
\hline IAR Eira barbara & 0 & 0 & 0.002 & 0 & 0 & 0.003 \\
\hline IAR Canis lupus familiaris & 0 & 0 & 0 & 0 & 0.01 & 0 \\
\hline \multicolumn{7}{|l|}{ Competitors } \\
\hline IAR Dasypus novemcinctus & 0 & 0.1 & 0 & 0 & 0.01 & 0.01 \\
\hline IAR Nasua narica & 0 & 0.01 & 0 & 0 & 0 & 0 \\
\hline IAR Dasyprocta punctata & 0 & 0 & 0 & 0 & 0 & 0.01 \\
\hline IAR Crax rubra & 0.01 & 0.01 & 0.02 & 0.04 & 0.04 & 0.05 \\
\hline IAR Iguana iguana & 0 & 0.01 & 0 & 0 & 0 & 0 \\
\hline IAR Procyon lotor & 0 & 0.01 & 0 & 0 & 0.01 & 0 \\
\hline IAR Pecari tajacu & 0 & 0 & 0 & 0.01 & 0 & 0.03 \\
\hline IAR Tayassu pecari & 0 & 0 & 0 & 0.01 & 0 & 0 \\
\hline IAR Tapirus bairdii & 0 & 0.01 & 0.01 & 0.01 & 0 & 0 \\
\hline IAR Odocoileus virginianus & 0 & 0 & 0 & 0 & 0.01 & 0 \\
\hline IAR Mazama temama & 0 & 0.01 & 0.01 & 0.01 & 0 & 0 \\
\hline IAR Didelphidae & 0 & 0.01 & 0 & 0 & 0.03 & 0.01 \\
\hline
\end{tabular}


Appendix 2. Tree species producing fruits potentially consumed by Cuniculus paca in the Lacandon Rainforest, Chiapas, Mexico, 2013-2014.

\begin{tabular}{|c|c|c|c|c|c|}
\hline Local name & Species & Family & Fruiting season ${ }^{a}$ & Fuit parts consumed ${ }^{b}$ & Source ${ }^{c}$ \\
\hline Aguacate silvestre & Beilschmiedia anay (Blake) Kosterm. & Lauraceae & 2 & $\mathrm{P}, \mathrm{S}$ & OC \\
\hline Amate & Ficus insipida Will. & Moraceae & 3 & FC & $\mathrm{OC}, \mathrm{L}$ \\
\hline Amatillo & Sapium lateriflorum Hemsl. & Euphorbiacea & 3 & FC & $\mathrm{L}, \mathrm{CL}$ \\
\hline Anona silvestre & Annona scleroderma Saff. & Anonaceae & 3 & FC & $\mathrm{OC}, \mathrm{L}$ \\
\hline Anonillo, Orejuelo & Cymbopetalum penduliflorum (Dunal) Baill. & Anonaceae & 3 & FC & $O C, L$ \\
\hline Barí & Calophyllum brasiliense Cambess. & Guttiferae & 2 & FC & L \\
\hline Cedrillo* & Guarea kunthiana A.Juss. & Meliaceae & 3 & FC & oC \\
\hline Colorado & Guarea glabra Vahl. & Meliaceae & 1 & FC & $\mathrm{L}, \mathrm{OC}$ \\
\hline Corozo* $^{*}$ & Attalea butyracea (Mutis ex L. f.) Wess. Boer & Arecaceae & 3 & $\mathrm{P}, \mathrm{C}$ & OC \\
\hline Espino & Acacia usumacintensis Lundell & Fabaceae & 1 & S & $\mathrm{CL}$ \\
\hline Frijolillo & Cojoba arborea (L.) Britton \& Rose & Fabaceae & 3 & FC & L \\
\hline Guapaque & Dialium guianense (Aubl.) Sandwith & Fabaceae & 3 & FC & L \\
\hline Guatope de río & Inga vera Willd. & Fabaceae & 2 & $\mathrm{P}, \mathrm{S}$ & L \\
\hline Guatopito de rio & Inga punctata Willd & Fabaceae & 2 & $\mathrm{P}, \mathrm{S}$ & L \\
\hline Guatopito verde de montaña & Inga laurina (sw.) Willd. & Fabaceae & 2 & $\mathrm{P}, \mathrm{S}$ & L \\
\hline Hule & Castilla elastica Cerv. & Moraceae & 2 & $\mathrm{P}, \mathrm{S}$ & $\mathrm{CL}$ \\
\hline Jaboncillo & Sapindus saponaria L. & Sapindaceae & 1 & FC & $\mathrm{CL}$ \\
\hline Jobo amarillo & Spondias mombin L. & Anacardiaceae & 2 & $C, P$ & OC, L \\
\hline Jobo verde* & Spondias radlkoferi Donn. Sm. & Anacardiaceae & 2 & $C, P$ & oC \\
\hline Luín & Ampelocera hottlei (Standl.) Standl. & Ulmaceae & 3 & FC & L \\
\hline Mamey & Pouteria sapota (Jacq.) H.E. Moore y Stearn & Sapotaceae & 2 & FC & OC, L \\
\hline Memela & Bellucia grossularioides (L.) Triana & Melastomataceae & 1 & FC & L \\
\hline Molinillo & Quararibea funebris (La Llave) Vischer & Malvaceae & 3 & FC & $\mathrm{OC}, \mathrm{L}$ \\
\hline Mulato & Bursera simaruba (L.) Sarg. & Burseraceae & 3 & FC & L \\
\hline Paterna & Inga pavoniana G.Don & Fabaceae & 2 & FC & L \\
\hline Ramon grande & Brosimum alicastrum Sw. & Moraceae & 2 & FC & L \\
\hline Ramon mediano & Brosimum lactescens (S. Moore) C. C. Berg & Moraceae & 2 & FC & $\mathrm{L}, \mathrm{CL}$ \\
\hline Sunzapote & Licania platypus (Hemsl.) Fritsch & Chrysobalanaceae & 2 & $\mathrm{P}, \mathrm{S}$ & $\mathrm{OC}, \mathrm{L}$ \\
\hline Volador & Virola guatemalensis (Hemsl.) Warb. & Myristicaceae & 2 & $\mathrm{P}, \mathrm{S}$ & L \\
\hline Zapotillo & Pouteria durlandii (Standl.) Baehni & Sapotaceae & 2 & FC & L \\
\hline
\end{tabular}

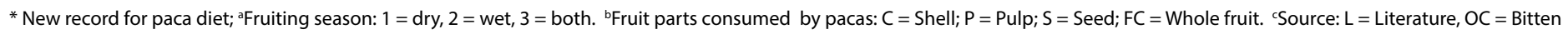
fruit observed in the field, $\mathrm{CL}=$ Reference by residents of the study area. 
HABITAT USE OF CUNICULUS PACA

208 THERYA Vol. 8 (3): 199-208 